\title{
$\mathrm{HACCP}$ 적용 농장의 병원성 세균 관리수준에 관한 연구 \\ 이지윤 ${ }^{1} \cdot$ 이주연 ${ }^{1} \cdot$ 백승희 $^{1} \cdot$ 황인진 $^{2} \cdot$ 이경순 $^{1} \cdot$ 김영수 $^{1} \cdot$ 김병훈 $^{1} \cdot$ 김현수 $^{1} \cdot$ 강수철 $^{1} \cdot$ 조재진 $^{1} \cdot$ 박민서 ${ }^{1} \cdot$ 석희진 $^{1} \cdot$ 남인식 $^{1 *}$ \\ 1축산물위해요소중점관리기준원, ${ }^{2}$ 국립수의과학검역원
}

\section{Study on the Management Level of Pathogenic Bacteria in HACCP System Implemented Animal Farms}

Gi-Yun Lee ${ }^{1}$, Joo-Yeon Lee ${ }^{1}$, Seung-Hee Back ${ }^{1}$, In-Jin Hwang ${ }^{2}$, Kyung-Soon Lee ${ }^{1}$, Young-Su Kim ${ }^{1}$, Byoung-Hoon Kim ${ }^{1}$, Hyun-Soo Kim ${ }^{1}$, Soo-Cheol Kang ${ }^{1}$, Jea-Jin $\mathrm{Cho}^{1}$, Min-Seo Park ${ }^{1}$, Hee-Jin Suk ${ }^{1}$ and In-Sik Nam ${ }^{1} *$

${ }^{1}$ Korea Livestock Products HACCP Accreditation Service, Anyang 430-731, Korea,

${ }^{2}$ National Veterinary Research and Quarantine Service, Anyang, 430-824, Korea

\begin{abstract}
The aim of this study was to understand the management level of pathogenic bacteria in HACCP system implemented animal farms. Microbial samples were collected from manure, floor, compost depot, manure on belt, low milk tank, dust in laying house and egg collector in HACCP system implemented Korean beef cattle, dairy cattle, swine, and laying Hens farms.

O157, O111 and $\mathrm{O} 26$ strains of E. coli were not detected in HACCP system implemented Korean beef cattle farm. The detection rate of $E$. coli from manure and floor in HACCP system implemented cattle farms (Korean beef cattle and dairy farm) was lower than those of non-HACCP system implemented cattle farm. Salmonella spp. was detected in HACCP system implemented cattle farms (Korean beef cattle and dairy farm). Compared with pervious studies, lower detection rate of Salmonella spp. at floor and compost depot in HACCP system implemented swine and commercial layer farms were indicated. In conclusion, implementation of HACCP system in animal farms would enhance the management level of biological hazard compare to normal animal farms.
\end{abstract}

(Key words : HACCP system, Pathogenic bacteria, Management, Farms)

\section{서 론}

국내 축산물 시장의 전면개방으로 인하여 미국산 소고기의 수입 과 한-미, 한-EU FTA 협상 타결로 인하여 국내 축산농가는 그 어느 때보다 어려움을 격고 있다. 이러한 이유로 북미, 유럽 등에 서는 자국 축산물의 국가 경쟁력 향상과 축산산업 보호를 목적으로 축산물의 안전관리제도 개발 등을 통하여 국제 축산물 교역에 효과 적으로 대처하고 있다.

축산물의 위생 - 안정성제고를 통하여 안전한 축산물을 소비자에게 제공하기 위해서는 가축이 사육되는 농장에서 식탁까지 위생 - 안전 관리 프로그램을 적용하여야 한다. 특히 대표적인 식중독 원인균인 Escherichia coli O157:H7, Salmonella spp. 및 Campylobacter spp. 등은 주로 축산물에서 기인되는 경우가 있으므로 우리나라를
비롯하여 각국 정부에서는 이를 근본적으로 예방 또는 허용수준 이 하로 감소시키기 위하여 많은 노력을 하고 있다(Schlundt, 2002; 이희수 등, 2004; Jo 등, 2004; O'Brien, 2005).

Hazard Analysis Critical Control Point (HACCP)는 과학적 근 거를 기초로 식품의 위해를 분석하고 이를 체계적으로 관리하기 위 하여 1950년대 말부터 개발되기 시작하였으며, 1993년 국제식품규 격위원회(Codex Alimentarius Commission)에서 식품에서 유래 되는 위해를 예방하기 위하여 각국에 $\mathrm{HACCP}$ 시스템도입을 권고 하고 있다. 국내에는 1997년 축산물가공처리법 개정으로 인하여 축산물에 대한 $\mathrm{HACCP}$ 제도가 도입되었으며 유럽, 미국 등 많은 나라에서 안전식품생산 프로그램 개발에 근본으로 $\mathrm{HACCP}$ 제도를 이용 및 적용하고 있다(국립수의과학검역원, 2004).

$\mathrm{HACCP}$ 의 기본 개념은 모든 축산물의 생산 및 가공, 판매 단계

* Corresponding author: In Sik Nam, Korea Livestock Products HACCP Accreditation Service, Anyang 430-731, Korea. Tel: 031-3905269, Fax: 031-390-6696, E-mail: insiknam@hotmail.com 
에서 발생 가능한 위해를 분석하고 이를 사전에 예방 또는 허용수 준 이하로 낮추어 축산물의 위생-안전성을 확보하여 소비자에게 안전한 축산물을 제공하기 위함이다(국립수의과학검역원, 2004).

국내 축산산업은 해방이후 지속적인 성장을 통하여 국민의 먹을 거리 창출에 앞장 서 왔다. 동시에 집약축산에서 발생하는 문제점 과 생산성을 높이기 위하여 미생물제제 및 항생제 대체제 등을 이 용한 생산성 향상에 관한 연구(장영달 등, 2009), 가축사육시설환 경개선에 관한 연구 (유용희 등, 2004; 송준익 등, 2005) 등을 통 하여 질병억제를 통한 생산성 향상과 고품질의 축산물 생산에 노력 해 왔다. 이와 함께 축산물의 안전성확보를 위하여 가축사육단계 $\mathrm{HACCP}$ 제도가 2006년 양돈농장 (농림수산식품부, 2006)을 시작 으로 도입되었으며, 비육우(농림수산식품부, 2007a)와 젖소(농림수 산식품부, 2007b)는 2007년, 육계 (농림수산식품부, 2008a)와 산란 계 (농림수산식품부, 2008b)는 2008년에 그리고 오리농장(농림수 산식품부, 2009) HACCP 제도는 2009년에 순차적으로 도입되었 다. 그러나 $\mathrm{HACCP}$ 적용 농장의 생물학적 위해 관리에 대한 연구 자료가 전무한 실정으로 이 분야에 대한 체계적이고 다양한 기초연 구가 필요할 것으로 판단된다. 따라서 본 연구는 각 축종별(한우, 젖소, 돼지, 산란계)로 $\mathrm{HACCP}$ 적용 농장의 분변, 원유 및 사육환 경에서 병원성세균 등 분석을 통하여 $\mathrm{HACCP}$ 적용 농장의 병원성 미생물 관리 실태를 파악하고 이를 농장 $\mathrm{HACCP}$ 시스템 적용에 관한 기초 연구 자료로 사용하는 것을 목적으로 하였다.

\section{재료 및 방법}

\section{1. 검체채취 대상 및 방법}

본 연구를 위한 검체채취 대상 및 방법은 다음과 같다. $\mathrm{HACCP}$ 를 운용중인 한우, 젖소, 돼지, 산란계 농장을 선택하여 분변, 퇴비 사, 원유, 축종별 사육환경에서 표면 샘플링을 실시하였다. 한우농 가 당 분변 5 건, 우사바닥 2건, 퇴비사 2건씩 총 9 건을 채취하였으 며, 젖소농가에서 분변 5 건, 우사바닥 2 건, 퇴비사 2 건, 원유 2 건으
로 11 건씩을 채취하였다. 돼지농장 당 분변 5건, 돈사바닥 2건, 퇴 비사 2건씩으로 총 9 건을 채취하였으며, 산란계농장도 분변 5건, 계사바닥 2건과 사육환경인 분변벨트, 계사내 먼지, 집란기에서 각 각 1 건, 1 건, 2 건으로 11 건씩 시료를 채취하였다. 시료 채취는 약 6 개월간 진행하였으며 한우와 젖소 각각 8 개 농장, 돼지 15 개 농 장, 산란계 5 개 농장으로 36 개의 농장에서 총 350 개의 샘플을 채 취하였다 (Table 1).

검체 채취는 무균적으로 SWAB kit를 사용하였다. 축종별로 분 변과 사육환경은 반드시 사육장 내에서 채취하였고 퇴비는 퇴비를 보관하고 있는 장소에서 채취하였으며 젖소 원유의 경우, 냉각기 에 보관된 상태에서 멸균된 PALCON tube에 $50 \mathrm{ml}$ 를 채취하여 밀봉하였다. 채취된 시료는 아이스박스에 아이스팩과 동봉하고 냉 장상태로 보관하여 운반한 후 냉장보관 36시간 안에 검사를 실시 하였다.

\section{2. 실험균주 선정}

분변과 사육환경에 광범위하게 오염되어 있으며 식품매개질환을 유발할 수 있는 병원성대장균(Pathogenic E. coli)과 살모넬라 (Salmonella spp.)를 대상으로 선정하였으며, 착유우의 유방염 원 인균인 황색포도상구균(Staphylococcus aureus)을 검사대상 균주 로 선정하였다.

\section{3. 균주 분리방법}

본 연구는 국립수의과학검역원고시 제2010-2호 ‘축산물의 가공 기준 및 성분규격 중 미생물 시험법에 (국립수의과학검역원, 2010) 따라 실시하였다. 병원성 대장균 시험방법은 다음과 같다. SWAB kit로 채취한 시료액 $25 \mathrm{ml}$ 를 $\mathrm{mEC}$ broth (novobiocin $20 \mu \mathrm{g} / \mathrm{ml}$ ) $225 \mathrm{ml}$ 에 $37^{\circ} \mathrm{C}$ 또는 $42^{\circ} \mathrm{C}$ 에서 $18 \sim 24$ 시간동안 증균배양하고, 증 균배양액을 Cefixime $(0.05 \mu \mathrm{g} / \mathrm{ml})$ 및 Potassium tellurite $(2.5 \mu \mathrm{g}$ $/ \mathrm{ml}$ )가 첨가된 SMAC와 Flurorocult E. coli O157 agar에 직접

Table 1. Farm numbers, animal species and microbial sample collection in HACCP system implemented farms

\begin{tabular}{ccccc}
\hline Animal species & Korean beef cattle & Lactating cattle & Swine & Laying Hens \\
\hline \hline Farm number & 8 & 8 & 15 & 5 \\
\hline & Manure & Manure & Manure & Manure \\
Microbial sample & Floor & Floor & Floor & Manure on belt \\
collection & Compost depot & Compost depot & Dow milk1 & Egg collector laying house \\
\hline
\end{tabular}

1) To detect S. aureus only, or the samples were collected from low milk tank in HACCP system implemented dairy farms. 
또는 적절히 희석 $\left(10^{-2} \sim 10^{-3}\right)$ 도말하여 $37^{\circ} \mathrm{C}$ 에서 24시간 배양하 였다. 배양 후 솔비톨을 분해하지 않는 집락 즉, $\mathrm{SMAC}$ 에서 무색 인 집락을 선별/Fluorocult 배지 상 녹색집락, $\mathrm{UV}$ 조사 아래 형 광을 나타내는 집락을 선별하여 각 평판당 5 개 이상씩 $\mathrm{Mac}-$ Conkey Agar 및 $\mathrm{EMB}$ Agar에 획선하여 $37^{\circ} \mathrm{C}$ 에서 24시간 배양 하였다. MacConkey Agar에서 lactose 분해균 및 EMB Agar에서 녹색성의 금속광택 집락에 대해 TSI로 $\mathrm{A} / \mathrm{A}$ (노란색/노란색)의 형 성균을 대상으로 대장균임을 확인하였다. 생화학성상시험은 API $20 \mathrm{E}$ 으로 확인하여 동정하였으며, $\mathrm{O}$ 항혈청 $(\mathrm{O} 157, \mathrm{O} 26, \mathrm{O} 111) \mathrm{kit}$ 를 이용하여 혈청학적 검사를 실시하여 혈청형을 확인하였다. 또한 병원성대장균의 5가지 병원성그룹인 enterohemorrhagic E. coli (EHEC), enterotoxigenic E. coli (ETEC), enteropathogenic $E$. coli (EPEC), enteroinvasive E. coli (EIEC), enteroaggregative E. coli (EAEC)는 멀티플렉스 PCR 방법을 사용하여 확인하였다. 이 PCR 방법은 Lopez-Saucedo 등 (2003)이 서술한 방법을 변형 하여 진행된 것으로, 먼저 주형 $\mathrm{DNA}$ 를 추출해내기 위하여 분리한 대장균을 TSB 배지에서 $37^{\circ} \mathrm{C}, 18$ 시간 이상 배양하였다. 배양액을 1 차 원심분리하여 남은 pellet을 $1 \mathrm{ml}$ 의 3 차 멸균증류수로 희석하 고 10 분간 $100^{\circ} \mathrm{C}$ 에서 열을 가하여 재차 원심분리 $15,000 \mathrm{rpm}$ 으 로 10 분간 진행하여 상층액을 분리하였다. 준비된 $\mathrm{PCR}$ 튜브에는 Tris- $\mathrm{HCl}(10 \mathrm{mM}, \quad \mathrm{pH} \quad 8.3), \quad \mathrm{KCl}(50 \mathrm{mM}), \quad \operatorname{MgCl}_{2}(2 \mathrm{mM})$, dATP, dCTP, dGTP, and dTTP $(200 \mu \mathrm{M}$ each $)$, Taq polymerase
(0.5 U/23 $\mu$ ) (iNtRON Biotechnology, Seoul, Korea)으로 구 성된 반응액과 16 개의 프라이머와 미리 분리해둔 상층액 주형 DNA $5 \mu$ 를 분주하였다. 사용된 프라이머 염기서열과 PCR 산물 의 증폭사이즈 등의 내용은 Table 2 와 같다. $\mathrm{PCR}$ 반응조건으로 1) 변성 (1 cycle: $95^{\circ} \mathrm{C}, 5$ 분간), 2) 결합 (40 cycle: 각 45 초씩 95 ${ }^{\circ} \mathrm{C}, 50^{\circ} \mathrm{C}, 72^{\circ} \mathrm{C}$ 온도변화), 3$)$ 합성 $\left(1\right.$ cycle: $72^{\circ} \mathrm{C}, 10$ 분간) 단계를 설정하였다. 그 결과는 전기영동을 통하여 확인하였다.

살모넬라 시험은 SWAB kit로 채취한 시료액 $25 \mathrm{ml}$ 에 $225 \mathrm{ml}$ 의 $\mathrm{BPW}$ 를 첨가하여 $36 \pm 1^{\circ} \mathrm{C}$ 에서 18 24시간 배양한 후 배양액을 2종류의 증균배지, 즉 $10 \mathrm{ml}$ 의 TT broth 또는 $\mathrm{SC}$ broth에 $1 \mathrm{ml}$ 를 첨가함과 동시에 $10 \mathrm{ml}$ 의 $\mathrm{RV}$ broth에 $0.1 \mathrm{ml}$ 를 첨가하여 각각 36 $\pm 1^{\circ} \mathrm{C}$ 및 $42 \pm 0.5^{\circ} \mathrm{C}$ 에서 $20 \sim 24$ 시간동안 증균 배양하였다. 각각의 증균배양액을 $\mathrm{BS}$ Agar 및 XLD Agar(또는 DCA, HE Agar, BS Agar) 배지에 도말한 후 $36 \pm 1{ }^{\circ} \mathrm{C}$ 에서 20 24시간 배양 결과 평판 별로 의심되는 집락 [(유당 비분해 (무색) 및 황화수소 $(\mathrm{H} 2 \mathrm{~S})$ 산성 으로 검은색) 3 개 이상을 취하여 TSI Agar 또는 LIA 사면배지에 천자하여 $37 \pm 1{ }^{\circ} \mathrm{C}$ 에서 $20 \sim 24$ 시간 배양하였다. TSI 및 LIA 검사 결과 살모넬라균으로 추정되는 균에 대해서는 API $20 \mathrm{E}$ 확인을 통 해 최종 동정하였다.

황색포도상구균은 PALCON tube에 채취해 온 원유 $10 \mathrm{ml}$ 를 90 $\mathrm{ml}$ 의 $10 \% \mathrm{NaCl}$ 을 첨가한 Tryptic Soy Broth에 접종하여 35 $37^{\circ} \mathrm{C}, 18$ 시간 증균배양하고 배양액을 Baird-Parker 배지에 도말하

Table 2. Target and primer sequences used in PCR assays for the identification of virulence genes of pathogenic E. coli

\begin{tabular}{|c|c|c|c|}
\hline Target & Primer & Sequence $\left(5^{\prime} \rightarrow 3^{\prime}\right)$ & PCR product size \\
\hline \multirow{2}{*}{ ETEC } & \multirow{2}{*}{$l t$} & GGCGACAGATTATACCGTGC & \multirow{2}{*}{450} \\
\hline & & CGGTCTCTATATTCCCTGTT & \\
\hline \multirow{2}{*}{ ETEC } & \multirow{2}{*}{ st } & ATTTTTCTTTCTGTATTGTCTT & \multirow{2}{*}{190} \\
\hline & & CACCCGGTACAAGCAGGATT & \\
\hline \multirow{2}{*}{ EPEC } & \multirow{2}{*}{ bfpA } & AATGGTGCTTGCGCTTGCTGC & \multirow{2}{*}{324} \\
\hline & & GCCGCTTTATCCAACCTGGTA & \\
\hline \multirow{2}{*}{ EPEC } & \multirow{2}{*}{ eaeA } & GACCCGGCACAAGCATAAGC & \multirow{2}{*}{384} \\
\hline & & CCACCTGCAGCAACAAGAGG & \\
\hline \multirow{2}{*}{ EHEC } & \multirow{2}{*}{ stxl } & CTGGATTTAATGTCGCATAGTG & \multirow{2}{*}{150} \\
\hline & & AGAACGCCCACTGAGATCATC & \\
\hline \multirow{2}{*}{ EHEC } & \multirow{2}{*}{ stx2 } & GGCACTGTCTGAAACTGCTCC & \multirow{2}{*}{255} \\
\hline & & TCGCCAGTTATCTGACATTCTG & \\
\hline \multirow{2}{*}{ EIEC } & \multirow{2}{*}{ ial } & GGTATGATGATGATGAGTCCA & \multirow{2}{*}{650} \\
\hline & & GGAGGCCAACAATTATTTCC & \\
\hline \multirow{2}{*}{ EAEC } & \multirow{2}{*}{ aafII } & CACAGGCAACTGAAATAAGTCTGG & \multirow{2}{*}{378} \\
\hline & & ATTCCCATGATGTCAAGCACTTC & \\
\hline
\end{tabular}


여 $37^{\circ} \mathrm{C}, 24$ 시간 배양한 결과 배지에서 보여지는 집락형태가 직경 1.0 1.5 mm, black, shiny, convex colony 주위에 약 2 5 mm의 opaque region이 관찰되면 의심집락으로 판단하여 보통 한천배지 (TSA)에 옮겨 $37^{\circ} \mathrm{C}, 18 \sim 24$ 시간 배양하였다. 배양결과 형성된 집 락을 혈액배지에 배양하여 용혈성 유무를 확인하며, 또 다른 집락 으로 coagulase test를 확인한다. 토끼혈청 (신선혈청은 5\%, 건조혈 청의 용액은 $10 \%)$ 을 가한 멸균생리식염수를 멸균한 시험관에 0.5 1 ml씩 무균적으로 분주하고 여기에 분리배지상의 집락에서 직접 또는 보통한천배지에서 순수배양 시킨 균 1 백금이를 접종하 여 $37^{\circ} \mathrm{C}$ 배양하여 $3,6,24$ 시간의 각 시간에 응고의 유무를 판정 하여 어느 시간 후에도 응고 또는 섬유소(fibrin)가 석출된 것은 모두 coagulase 양성으로 하며 이상과 같이 확인된 것은 황색포도 상구균 양성으로 판정하였다.

\section{결 과}

1. 분뇨 및 사육환경에서 대장균 검출

$\mathrm{HACCP}$ 시스템을 운용중인 농장의 축종별 분뇨, 바닥, 퇴비사, 분변벨트 및 집란기의 병원성 대장균 검출결과는 Table 3 과 같다.
각 농장의 축종별 대장균은 분변에서 $100 \%$ 검출되었다. 바닥에서 는 산란계농장에서 가장 높은 검출율을 보였으며 $(100 \%)$, 한우와 돼지농장의 바닥에서는 약 $30 \sim 40 \%$ 의 대장균이 검출되었다. 그러 나 젖소농장에서는 $18.8 \%$ 의 대장균이 검출되어 모든 축종 중 가장 낮게 나타났다. 퇴비사나 분변벨트에서는 돼지농장과 산란농장에서 가장 높은 대장균 검출율을 나타내었으며, 다음으로 젖소농장 $25 \%$, 한우농장 $18.8 \%$ 순으로 낮았으며 전체적으로 $62.7 \%$ 의 대장 균 검출율을 나타내었다. 산란계농장 내 시설 중 집란기의 대장균 오염정도를 확인하였으나 검출되지 않았다.

각 농장에서 분리된 대장균을 병원성그룹 별로 분리한 결과는 Table 4와 같다. 한우농장의 분뇨에서 분리한 대장균 검출건수 16 건 중 장관출혈성대장균이 11 건 $(27.5 \%)$ 를 차지하였으며 장관독소 원성대장균은 5 건 $(12.5 \%)$ 으로 나타나 장관출혈성대장균이 상대적 으로 높은 비율을 차지하였다. 반대로 젖소농장에서는 장관출혈성 대장균 5 건 (12.5\%) 보다 장관독소원성대장균이 13건 (32.5\%)으로 높게 조사되었다. 돼지농장의 분뇨에서 분리한 대장균은 전체 75회 분석대비 9건 $(12.0 \%)$ 이 장관출혈성대장균으로 조사되었으며 1건 $(1.3 \%)$ 은 장관병원성대장균으로 조사되었다. 산란계농장에서도 한 우 및 젖소와 비슷한 경향을 나타내었는데, 전체 25 건의 분뇨에서 5 건 $(20.0 \%)$ 이 장관출혈성대장균이었고 4 건 $(16.0 \%)$ 이 장관독소원

Table 3. Detection rate of $E$. coli sampled from manure and farm environments in HACCP system implemented animal farms

\begin{tabular}{|c|c|c|c|c|c|}
\hline Animal species & Items & Manure & Floor & $\begin{array}{c}\text { Compost depot or Manure } \\
\text { on belt }\end{array}$ & Egg collector \\
\hline & No. of sample collection & 40 & 16 & 16 & - \\
\hline \multirow[t]{3}{*}{ Korean beef cow } & No. of detection & 40 & 5 & 3 & - \\
\hline & Detection rate $(\%)$ & 100.0 & 31.3 & 18.8 & - \\
\hline & No. of sample collection & 40 & 16 & 16 & - \\
\hline \multirow[t]{3}{*}{ Dairy cow } & No. of detection & 40 & 3 & 4 & - \\
\hline & Detection rate $(\%)$ & 100.0 & 18.8 & 25.0 & - \\
\hline & No. of sample collection & 75 & 30 & 30 & - \\
\hline \multirow[t]{3}{*}{ Swine } & No. of detection & 75 & 12 & 30 & - \\
\hline & Detection rate $(\%)$ & 100.0 & 40.0 & 100.0 & - \\
\hline & No. of sample collection & 25 & 10 & 5 & 10 \\
\hline \multirow[t]{3}{*}{ Laying Hens } & No. of detection & 25 & 10 & 5 & 0 \\
\hline & Detection rate $(\%)$ & 100.0 & 100.0 & 100.0 & 0.0 \\
\hline & No. of sample collection & 180 & 72 & 67 & 10 \\
\hline \multirow[t]{2}{*}{ Overall } & No. of detection & 180 & 30 & 42 & 0 \\
\hline & Detection rate $(\%)$ & 100.0 & 41.7 & 62.7 & 0.0 \\
\hline
\end{tabular}


Table 4. Classification of pathogenicity groups of $E$. coli sampled from manure and farm environments in HACCP system implemented animal farms

\begin{tabular}{|c|c|c|c|c|c|c|}
\hline \multirow{2}{*}{ Animal species } & \multirow{2}{*}{$\begin{array}{c}\text { Sample } \\
\text { collecting points }\end{array}$} & \multirow{2}{*}{$\begin{array}{l}\text { No. of sample } \\
\text { collection }\end{array}$} & \multicolumn{4}{|c|}{ Pathogenicity groups } \\
\hline & & & EHEC $^{1)}$ & ETEC $^{2)}$ & $\mathrm{EPEC}^{3)}$ & EIEC $^{4)}$ EAEC $^{5)}$ \\
\hline \multirow{3}{*}{$\begin{array}{c}\text { Korean beef } \\
\text { cow }\end{array}$} & Manure & 40 & $11(27.5 \%)$ & $5(12.5 \%)$ & - & - \\
\hline & Floor & 5 & - & - & - & - \\
\hline & Compost depot & 3 & - & - & - & - \\
\hline \multirow{3}{*}{ Dairy cow } & Manure & 40 & $5(12.5 \%)$ & $13(32.5 \%)$ & - & - \\
\hline & Floor & 3 & - & - & - & - \\
\hline & Compost depot & 4 & - & - & - & - \\
\hline \multirow{3}{*}{ Swine } & Manure & 75 & $9(12.0 \%)$ & - & $1(1.3 \%)$ & - \\
\hline & Floor & 12 & - & - & - & - \\
\hline & Compost depot & 30 & - & - & $1(3.3 \%)$ & - \\
\hline \multirow{3}{*}{$\begin{array}{c}\text { Laying } \\
\text { Hens }\end{array}$} & Manure & 25 & $5(20.0 \%)$ & $4(16.0 \%)$ & - & - \\
\hline & Floor & 10 & - & - & - & - \\
\hline & Manure on belt & 5 & - & - & - & - \\
\hline \multirow{3}{*}{ Overall } & Manure & 180 & $30(16.7 \%)$ & $22(12.2 \%)$ & $1(0.5 \%)$ & - \\
\hline & Floor & 30 & - & - & - & - \\
\hline & $\begin{array}{l}\text { Compost depot or } \\
\text { Manure on belt }\end{array}$ & 42 & - & - & 1 & - \\
\hline
\end{tabular}

${ }^{1)}$ EHEC; enterohemorrhagic E. coli ${ }^{2)}$ ETEC; enterotoxigenic E. coli

${ }^{3)} \mathrm{EPEC}$; enteropathogenic E. coli $\quad{ }^{4)} \mathrm{EIEC}$; enteroinvasive E. coli

${ }^{5)}$ EAEC; enteroaggregative E. coli

성대장균으로 조사되었다. 따라서 국내에서 사육되고 있는 가축의 장내에는 장관출혈성대장균 $(30 / 180,16.7 \%)$ 이 가장 많이 존재하 고 그 다음으로 장관독소원성대장균 $(20 / 180,12.2 \%)$ 순으로 존재 하는 것으로 보인다.

2. 분뇨, 원유 및 사육환경에서 Salmonella spp. 및 $S$. aurues 검출

$\mathrm{HACCP}$ 지정 소, 돼지, 닭 농가의 분뇨, 원유, 퇴비사 및 분변 벨트에서 Salmonella spp. 및 S. aurues 검출 결과는 Table 5 와 같다. 한우농장과 젖소농장에서 채취한 분뇨, 바닥 및 퇴비사에서 는 Salmonella spp. 가 검출되지 않았다. 또한 젖소농장의 원유 냉 각기에서도 S. aurues가 검출되지 않았다. 마찬가지로 돼지농장과 산란계농장의 분뇨 및 분변벨트에서는 Salmonella spp.가 검출되 지 않았다. 그러나 돼지농장의 돈사바닥 및 퇴비장에서는 30 건당 각각 2건, 1건씩 Salmonella spp.가 검출되었으며 마찬가지로 산
란계농장의 계사바닥 및 분변벨트에서도 전체분석 건수 대비 10 $20 \%$ 가 검출되었다.

\section{고 찰}

본 연구는 $\mathrm{HACCP}$ 시스템을 운용중인 국내 농장의 병원성미생 물 오염도를 조사하여 농가의 생물학적 위해관리 수준을 파악하여 농장 $\mathrm{HACCP}$ 시스템 연구에 대한 기초 자료로 활용할 목적으로 실시하였다.

분변검체로부터 분리된 대장균은 축종에 상관없이 모두 180 건 $(100 \%)$ 이 검출되었으나, 설사, 장염 등 치명적인 질병을 유발하는 병원성대장균으로는 53 건 (29.4\%)로 나타났으며, 이중 대부분의 가 축에게 설사를 유발시키는 병원성대장균(ETEC)은 22 건 $(12.2 \%)$ 으로 조사되었다. 특히 돼지 설사 유발 대장균인 $\mathrm{EPEC}$ 는 돼지분 변에서 1 건 $(1.3 \%)$ 에서 확인되었으며, 돼지의 부종병, 송아지의 출 혈성장염을 초래할 수 있는 대장균인 $\mathrm{EHEC}$ 는 한우에서 가장 많 
Table 5. Detection of Salmonell spp. and Staphylococcus aureus sampled from manure, farm environments and low milk in HACCP system implemented animal farms

\begin{tabular}{|c|c|c|c|c|c|}
\hline Animal species & Items & Manure & Floor & $\begin{array}{l}\text { Compost depot or Manure } \\
\text { on belt }\end{array}$ & Low milk ${ }^{1)}$ \\
\hline \multirow{3}{*}{$\begin{array}{l}\text { Korean Beef } \\
\text { cow }\end{array}$} & No. of sample collection & 40 & 16 & 16 & - \\
\hline & No. of detection & 0 & 0 & 0 & - \\
\hline & Detection rate $(\%)$ & 0.0 & 0.0 & 0.0 & - \\
\hline \multirow{3}{*}{ Dairy cow } & No. of Sample collection & 40 & 16 & 16 & 16 \\
\hline & No. of detection & 0 & 0 & 0 & 0 \\
\hline & Detection rate $(\%)$ & 0.0 & 0.0 & 0.0 & 0.0 \\
\hline \multirow{3}{*}{ Swine } & No. of Sample collection & 75 & 30 & 30 & - \\
\hline & No. of detection & 0 & 2 & 1 & - \\
\hline & Detection rate $(\%)$ & 0.0 & 6.7 & 3.3 & - \\
\hline \multirow{3}{*}{$\begin{array}{c}\text { Laying } \\
\text { Hens }\end{array}$} & No. of Sample collection & 25 & 10 & 5 & - \\
\hline & No. of detection & 0 & 1 & 1 & - \\
\hline & Detection rate $(\%)$ & 0.0 & 10.0 & 20.0 & - \\
\hline \multirow{3}{*}{ Overall } & No. of Sample collection & 100 & 40 & 35 & 16 \\
\hline & No. of detection & 0 & 3 & 2 & 0 \\
\hline & Detection rate $(\%)$ & 0.0 & 7.5 & 5.7 & 0.0 \\
\hline
\end{tabular}

\footnotetext{
${ }^{1)}$ To detect $S$. aureus only, or the samples were collected from low milk tank in HACCP system implemented dairy farms.
}

은 검출율을 보였으나 항 혈청분석 결과 주요 출혈성대장염 원인인 혈청형 $\mathrm{O} 157, \mathrm{O} 111, \mathrm{O} 26$ 은 발견되지 않았다. 권 등(권영길 등, 2007)의 연구결과에 의하면 국내에서 사육중인 소, 돼지, 닭 분변 에서의 대장균 검출율은 $100 \%$ 라고 보고하였는데 이러한 결과는 본 연구결과와 일치하였다. Jeon 등 (2006) 연구결과에서는 국내 일반 소농가에서 채취한 분변으로부터 장관출혈성대장균 중에서 $\mathrm{O} 26$ 혈청을 가진 대장균 54건 (6.7\%), O111혈청인 대장균 37 (4.6\%)건이 분리되어 본 연구결과에 비하여 높게 나타났다. 대장균 은 사람 및 동물의 장내 상재균이나 장관 내외에서 각종 감염증을 일으키고 의학 및 공중위생뿐만 아니라 축산업에서도 중요한 병원 균으로서의 위치를 점하고 있다(송희종 등, 1998). 특히 돼지와 가 금류에서 각종 질병을 유발시키는 병원성대장균은 높은 이병율과 폐사율로 인한 심각한 경제적 손실을 초래하므로 축산분야에서 전 세계적으로 중요시 되고 있는 질병이다(성명숙 등, 2008).

일반 소(젖소, 한우)농장의 퇴비에서는 $42.9 \%$ 의 대장균이 검출 되는 것으로 보고되었으나(권영길 등, 2007), 본 연구에서
$\mathrm{HACCP}$ 적용 소농장의 바닥 및 퇴비에서는 대장균 검출율은 각각 $25.0 \%, 21.9 \%$ 로 조사되었다. 그러나 산란계농장의 바닥과 돼지농 장의 퇴비 및 분변벨트에서는 높은 대장균 검출율을 나타내어 이에 대한 철저한 소독 등 위생관리 방안이 추가되어야 할 것으로 판단 된다.

농장 살모넬라속균 오염에 대한 국내 보고를 살펴보면 일반적으 로 국내 닭농장의 $20 \%$ 가 오염된 것으로 추정하고 있으며, 돼지농 장은 약 $30 \%$ 가 오염된 것으로 보고되고 있다 (권영길 등, 2007). 국외의 경우 돼지농장의 살모넬라균 오염비율은 최대 $48 \%$ 까지 보 고(Haddock, 1970; Jayaro 등, 1979; Alier 등, 1989)되고 있어 국내와 비슷한 실정이다. 이는 사육농가의 위생 상태나 사육환경 등의 차이에 의한 것으로 추정된다(황원무 등, 2004). 본 연구에서 는 소, 돼지, 산란계의 분변에서는 살모넬라균이 검출되지 않았으 나 주변 사육환경 (바닥, 퇴비, 분변벨트)에서는 소 농장을 제외하 고 돼지와 닭 농장 바닥과 퇴비사에서 각각 3 건 $(7.5 \%), 2$ 건 (5.7\%)씩 검출되었는데 이는 지금까지 보고된 국내외 살모넬라오 
염비율에 비하여 상당히 낮은 것으로 조사되었다. 살모넬라속균은 동물과 사람에 감염되어 장염, 위장염, 패혈증을 일으키는 병원성 장내세균으로 숙주가 다양하고 인수공통전염성 원인균으로 환경이 나 식품오염을 통하여 식중독을 일으키므로 공중보건학상 대단히 중요시되고 있다(정영미 등, 2004). 닭에서는 주로 오염된 어분이 함유된 배합사료를 섭취하거나 보균동물의 배설물에 의해 수평감염 이 이루어지고 있지만, 모계를 통한 수직감염도 질병전파에 매우 중요한 형태로 보고되고 있으므로 (정영미 등, 2004) 사료공장에의 원료관리, 사료하치장에서의 제품사료관리, 농장에서의 사료관리 등 에 각별한 관심을 기울여야 할 것으로 판단된다.

원활하고 안정적인 낙농행위를 위해서는 무엇보다 중요한 것이 착유우의 질병관리와 사양관리이다. 착유우가 유방염에 걸릴 경우 평균 산유량 감소비율이 $5 \%$ 에서 $25 \%$ 범위이고 심할 경우 $85 \%$ 까 지 감소한다(Janzen, 1979). 유방염 원인균중 가장 심각한 세균은 S. aurues로 국내 낙농농가에서 가장 흔하게 검출되고 있다(박준 규 등, 2000). $\mathrm{HACCP}$ 시스템이 적용되고 있는 낙농농가의 $S$ aurues 관리수준을 파악하기 위하여 원유탱크에서 검체를 취하여 검사한 결과 S. aurues 검출되지 않은 것으로 보아 본 시험에 선 정된 농가는 $\mathrm{HACCP}$ 매뉴얼에 따라 원유내 $S$. aurues를 잘 관리 하고 있는 것으로 판단된다.

본 연구결과를 종합해 보면 $\mathrm{HACCP}$ 시스템을 운용중인 농가의 병원성세균관리 수준을 일반 축산농가와 간접 비교하였을 경우 다 소 향상되는 것으로 조사되었는데 이는 $\mathrm{HACCP}$ 시스템 중 선행요 건프로그램에 의한 것으로 판단된다.

\section{요 약}

본 연구는 한우, 젖소, 돼지, 산란계 $\mathrm{HACCP}$ 적용 농장의 분변, 원유 및 사육환경에서 병원성세균 등 분석을 통하여 $\mathrm{HACCP}$ 적용 농장의 생물학적 위해 관리 실태를 파악하고자 하고 이를 농장 $\mathrm{HACCP}$ 시스템 적용에 관한 기초 연구 자료로 사용하는 것을 목 적으로 하였다. 미생물 시료는 $\mathrm{HACCP}$ 을 적용 중인 한우, 젖소, 돼지, 산란계농장의 축사바닥분뇨, 퇴비사, 원유탱크, 집란기, 분변 벨트 등에서 채취 하였으며 축산식품의 생물학적 위해인 Pathogenic E. coli, Salmonella spp. S. aureus 등을 분석하였다.

각 축종별 대장균은 분변에서 $100 \%$ 검출되었으나 Salmonella $s p p$.는 검출되지 않았다. 또한 젖소농장의 원유 냉각기에서도 $S$ aurues가 검출되지 않았다. 그러나 돼지농장의 돈사바닥 및 퇴비장 에서는 검사건수 30 건당 각각 2건, 1건의 Salmonella spp.가 검출 되었다. 마찬가지로 산란계농장의 계사바닥 및 분변벨트에서도 전 체분석 건수 대비 $10 \sim 20 \%$ 의 Salmonella spp.가 검출되었다. 이러 한 결과는 문헌상 보고되고 있는 일반축산농가의 병원성세균 관리 실태와 간접 비교하였을 경우 $\mathrm{HACCP}$ 시스템을 적용중인 축산농
가에서의 일반축산농가보다 병원성 세균관리가 더욱 철저히 이루어 지고 있는 것으로 판단된다.

(주제어: 축산물위해요소중점관리시스템, 병원성 세균, 농장)

\section{인 용 문 헌}

Alier, A., Mafu, R. and Higgins, M. 1989. The Incidence of Salmonella, Campylobacter, and Yersinia enterocolitica in swine carcasses and the slaughterhouse Environment. J. Food Prot. 52, 642-645.

Haddock, R. L. 1970. Efficacy of examining rectal swabs to detect swine Salmonella carriers. Am. J. Vet. Res. 31, 1509-1516.

Janzen, J. J. 1979. Economic losses resulting from mastitis. a review. J. Dairy Sci. 53, 1151-1161.

Jayaro, B. M., Biro, G., Kovacs, S., Domján, H. and Fábián, A. 1989. Prevalence of Salmonella serotypes in pigs a nd evalution of a rapid, presumptive test for detection of Salmonella in pig feces. Acta Vet Hung. 37, 399-444.

Jeon, B. W., Jeong, J. M., Won, G. Y., Park, H., Eo, S. K., Kang, H. Y., Hur, J. and Lee, J. H. 2006. Prevalence and characteristics of Escherichia coli $\mathrm{O} 26$ and $\mathrm{O} 111$ from cattle in Korea. Int. J. Food Microbiology. 110, 123-126.

Jo, M. Y., Kim, J. H., Lim, J. H., Kang, M. Y., Koh, H. B., Park, Y. H., Yoon, D. Y., Chae, J. S., Eo, S. K. and Lee, J. H. 2004. Prevalence and characteristics of Escherichia coil $\mathrm{O} 157$ from major food animals in Korea. Int. J. Food Microbiol. 95, 41-49.

Lopez-Saucedo, C., Cerna, J. F., Villegas-Sepulveda, N., Thompson, R., Velazquez, F. R., Torres, J., Tarr, P. I. and Estrada-Garcia, T. 2003. Single multiplex polymerase chain reaction to detect diverse loci associated with diarrheagenic Escherichia coli. Emerg. Infec. Dis. 9, 127-131.

O'Brien, S. J. 2005. Foodborne zoonoses. Br. Med. J. 331, 12171218.

Schlundt, J. 2002. New directions in foodboren disease prevention. Int. J. Microbiol, 78, 3-17.

국립수의과학검역원. 2004. 위해요소중점관리기준 (HACCP) 백서.

국립수의과학검역원. 2010. 축산물의 가공기준 및 성분규격.

권영일, 김태운, 김해영, 장윤희, 곽효선, 우건조, 정윤희. 2007. 국내 축산 환경 중의 항생제 내성균 모니터링에 관한 연구. 한국미생물생명공학 회. $35,17-25$.

농림수산식품부. 2006. 돼지사육단계위해요소 중점관리기준 (HACCP) 적용 지침 및 모델.

농림수산식품부. 2007a. 비육우사육단계위해요소 중점관리기준 (HACCP) 적용지침 및 모델.

농림수산식품부. $2007 \mathrm{~b}$. 젖소사육단계위해요소 중점관리기준 $(\mathrm{HACCP})$ 적 용지침 및 모델. 
농림수산식품부. 2008a. 육계사육단계위해요소 중점관리기준 $(\mathrm{HACCP})$ 적 용지침 및 모델.

농림수산식품부. 2008b. 산란계사육단계위해요소 중점관리기준(HACCP) 적용지침 및 모델.

농림수산식품부. 2009. 오리사육단계위해요소 중점관리기준 (HACCP) 적용 지침 및 모델.

박준규, 임재향, 서영동, 김내영, 임동영, 윤선종, 최종성, 고홍범. 2000. 전 남도내 사육중인 젖소유래 staphlococcus aureus의 enterotoxin 생성 과 coagulase 아형분석에 관한 연구. 한국가축위생학회. $23,313-320$. 성명숙, 김진현, 하종수, 조재근, 설성용, 김기석. 2008. 가금 유래 병원성 대장균의 생화학적 성상 및 혈청형. 한국가축위생학회. 48, 145-151. 송준익, 김태일, 최희철, 우용희, 정종원, 연규영, Antonio Barroga, 양창범, 김두환, 김준우. 2005. 무창 육성비육돈사에서의 biofilter에 의한 악취 제어효과. 한국동물자원과학회. $11,55-60$.

송희종, 채효석. 1998. 가축에서 대장균 감염증. 한국가축위생학회. 21, 413-429.
유용희, 송준익, 정종원, 김태일, 최희철, 양창범, 이영윤. 2004. 무창 분만 - 자돈사내에서 환기시스템별 혹환기 환경조사. 한국축산시설환경학회. $10,23-28$.

이희수, 임숙경, 조윤상, 주이석, 김재학, 김종만. 2007. 살모넬라 세포외막 단백질 혼합백신을 이용한 돼지 및 닭에서의 살모넬라감염증 방어효과. 대한수의학회. 47, 147-155.

장영달, 오희경, 박용국, 최현봉, 윤진현, 김유용. 2009. 항생제 대체제로서 생균제가 이유자돈의 성장능력 및 영양소 이용률, 설사 빈도, 면역 반 응에 미치는 영향. 한국동물자원과학회. $51,25-32$.

정영미, 김기주, 엄성심, 이지영, 노영선, 서석열, 박정배, 이희문, 정동석. 2004. 전북 남원지역 육계에서 살모넬라증에 대한 역학적 조사. 한국 가축위생학회. 27, 75-80.

황원무, 이성모, 황현순, 한정희. 2004. 인천지역 도축장에서 생산된 돼지고 기의 미생물 오염도 조사. 한국가축위생학회. 27, 7-15.

(Received June 17, 2010; Revised October 6,2010; Accepted November 7, 2010) 